http://www.jfas.info

\title{
EVALUATION OF SOCIAL CAPITAL IN HISTORIC URBAN TISSUE (CASE STUDY: THE HISTORIC TISSUE OF KERMAN CITY)
}

\author{
A. Najmeh Eshaghi ${ }^{*}$ and B. Hamid Mohammadi \\ Faculty of Arts and Architecture, Yazd University, Yazd, Iran
}

Published online: 15 May 2016

\begin{abstract}
Today Social Capital as one of the most important comprehensive development factors is a key concept in new attitude to urban planning and management. In this attitude, planning is based on human resources, social capitals and collaborative participation. The social capital in historic tissue is considered from two aspects of view: 1.Increasing realization of development plans related to this valuable tissue 2.Gradation in social status of this tissue among society. Studying the concept and importance of social capital, this research evaluated the extent of social capital in historic tissue of Kerman city by means of AHP (Analytical Hierarchy Process) technique and through four indicators of Trust, Social Participation, collaboration and Sense of Security. The method of current research is applied, the data is collected by desk study and the survey is done by interview and questionnaire.
\end{abstract}

Keywords: Historic tissue, Social Capital, Comprehensive Development.

Author Correspondence, e-mail: n_es2000@yahoo.com

doi: http://dx.doi.org/10.4314/jfas.v8i3s.260

\section{INTRODUCTION}

\subsection{Problem Statement}

Due to residence of poor and diverse people in terms of ethic and society (migrants and 
foreigners) and for various reasons including poverty, lack of sense of life, impressment and proficiency in habitants, historic tissue is in undesirable condition. Insecurity, distrust, Social harms, and incoherence and etc. represent this subject and since the Social Capital as an important issue is the prerequisite of urban and economic comprehensive development, the need for exhausting this subject is as much again. In this study white expressing the importance of the subject, the social capital in historic tissue is evaluated as a means for inhabitant's participation in implement of development plans and establishment of a sense of belonging to their residential environment to dive in.

\subsection{Importance and necessity}

In the approach of Capital based urban development, all the social capital of local community (including corporal and in corporal) forms the foundation of development. The social capital, as compared with other properties of a society has a particular importance which can stimulate urban development since it causes people to use other capitals including intellectual and financial to improve their living environment; in other words, it is a proven fact that the level of social capital influences the extent of inhabitants participation in improvement plan of the neighborhood [1].Therefore considering the social capital in various development plans and also improvement of historic tissue by authorities and planner is necessary.

\subsection{Goals}

- Evaluating the extent of social capital in historic tissue.

- Increasing implementation of development plans of historic tissue by means of capacity creation.

- Promoting of cultural and social situation of historic tissue among the community.

\subsection{Literature Review}

In the middle of 1990s while the World Bank was planning sustainable development policies, the politic consequence of social capital for development has generally been considered as consultant workshops there. These ideas has been used in poverty alleviation plans of the bank which are based on local community improvement, collaborative participation of neighborhood in decision making, capacity creation in local organizations and selecting accountable projects to local demands[2]. 
Social capital besides democracy and civil society in social science of late 20 s are all-purpose. Before publication of Robert Putnam's famous book, Democracy and Civic Tradition, only 10 essays about Social Capital has been published but in 15 years later t0 2007, the average annual essays with this topic were 160 and the registered references to the essays in data bank of SSCI are 1500[3].

In these essays various fields including sociology, economy, management, hygiene, politics, psychology, planning and improvement of organization, have confirmed the influence of social capital on economic growth, higher education, financial extension, innovation, general hygiene and reduction of suicide, violence and financial crimes[3].

\subsection{Research Method}

The research method of current study is applied and desk study. Direct reference to the study range, identification and analysis of various dimensions and aspects of the social capital rate is performed, accordingly the first part of data analytical and descriptive citing desk studies and the second part is collected hierarchically by questionnaire and interview and then the analysis of the survey data for determination of quantity level of every indicators of social capital of this tissue.

\subsection{Study Range}

\subsubsection{Historic Tissue of Kerman}

What currently known as historic tissue of Kerman is undoubtedly part of city that is in disorder and imbalance. This part of city which in an earlier time has effective role as efficient and coherent center is now changed to one of the most irregular and abandoned parts of city, that in addition to dissatisfaction of inhabitants, other citizens are disaffected to inhabit. In spite of many plans, in two decades, titled the revival of Kerman historic tissue, the historic center of city, the structural design of Kerman city, the strategic plan for protecting and revival of historic tissue and ..., which is provided for this district that a very low percentage has been fulfilled and it is affected with many physical problems besides social. Kerman historic tissue is holding a central part including bazar and other related complex limited between Taleghani and Shariati Streets, Moshtaq Square and Imam Khomeini Street and a fringe part mainly included old neighborhood, neighborhood centers and a few precious 
monuments. In this study central part limited between Taleghani and Shariati streets, Moshtaq square and Imam Khomeini Street is investigated as the study area (fig.1).

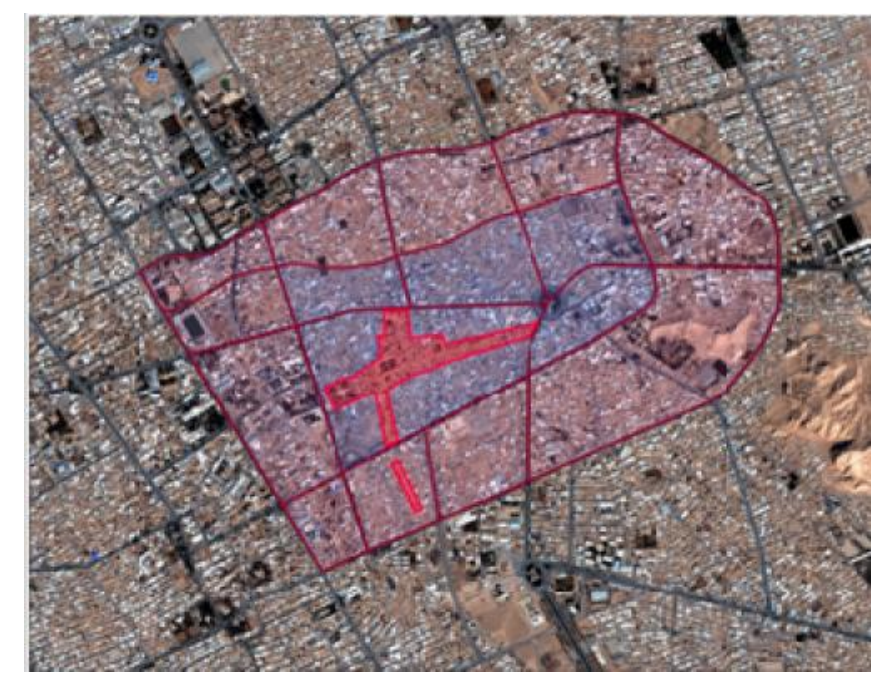

Fig.1. The historic tissue of Kerman city (central and fringe parts)

\section{THEORETICAL VIEWS}

\subsection{Social Capital}

Nowadays development literature with the transition from mere attention to physical capitals, has considered effective capitals in the development process such as natural, human and social capitals [4].The concept of social capital is generally the resources which are the legacy of social relations and facilitate collaborative action. The resources achieved through socializing involve trust, participation norms and networks of social links that cause people to gather coherently and stably in groups for obtaining a common goal [5]. Social Capital represented in collaborative interactions, focused on constructive goals and consists of in-group, out-group and vertical types. In group is based on relations of people with familiarity, out-group according to stranger relation with each other and vertical depends on relations of people in different levels of hierarchy and power. The social capital, a process unlike physical and human capital, is not formed from available sources of people but it is a process of social interactions that lead to productive results. Variability, being conditional and background dependence of this process complicate changing of social capital [3].

For the first time, sociologists introduced the concept of social capital. Since 1980 and later, this concept entered to social science literature especially sociology. At first "Jane Jacobs" 1961 and "Bourdieu" 1986 mentioned the primary concept of social capital. Then others like 
"Colman" 1988 and "Putnam" 1993 elaborate it [6].The roots of relation between social capital and urban problems can be found in "The Death of Life of Great American Cities" written by Jane Jacobs. From her point of view, intensive social networks in old and mixed-use suburbs, form an aspect of social capital comparing with official institutions such as police act more responsible about cleanliness, absence of street crime and other decisions to improve the quality of life. Bourdieu performed the first regular analysis of social capital. This analysis is the most accurate one which generate the concept of social capital in contemporary sociology discourse [7]. Bourdieu believes that economic capital is the main root of all capitals. He also wants to know how it combines with other capitals to regenerating inequality. Based on Bourdieu's viewpoint, inequality should be explained by generating and regenerating capital. He believes, considering capital just from an economic viewpoint is not sufficient [8]. Another theorist who developed ideas about social capital after Bourdieu is Colman. He uses this concept to explain the possibility of cooperation between individuals. The social capital in his studies has an extended position and included the basis of social discipline [9]. Putnam in the description of social capital writes: "Social capital means various aspects of social concepts like trust, norms and networks which improve proficiency of society by facilitation of coordinated acts". In other words, social capital includes both structural (networks) and cultural (norms, social values and trust) aspects. He believes Social capital like other capitals is a generator that allows achieving special goals which are unavailable without it; for example members of a group which behave reliably and trust to one another comparing with a group without these features can do more actions. More precisely, the social capital is helpful in manners; it means that social capital increases potential expenses of faithlessness in every dealing, strengthens the strong norms of mutual action, and facilitates communications. Reliability will improve the process of information and act like the clear cultural frame for future cooperation. On the subject of the possession of social capital, he believes that social capital on the contrary of other common capitals is public so is not in a private possession of its beneficiaries. The social capital is like other public goods (clean weather and safe streets) that correspondents of private section have no tendency to produce. It means that social capital should often be produced by other social 
actions. This capital is usually formed in connections, norms and trust which is transferred from a social situation to another one. According to Putnam's view, voluntary cooperation in a society which has inherited social capital in the form of reciprocation norms and civic participation networks is better [10].

\subsubsection{Social Capital Dimensions}

The social capital includes two sections, structural (social networks) and normative (trust, knowledge, establish norms of cooperation and reciprocal relations). The foregoing elements and principles can produce prospective profits of social capital in encounter with each other. To conclude the expressed comments, the social capital can be known as a group of networks, norms, values and understanding which facilitate the cooperation between and in groups fore achievement of reciprocal profits[11] (Table 1).

Table 1. Social Capital Dimentions

\begin{tabular}{|c|c|c|}
\hline Variable & Dimension & $\begin{array}{r}\text { Dimension Division } \\
\end{array}$ \\
\hline \multirow{13}{*}{ Social capital } & \multirow{5}{*}{ Trust } & Formal trust \\
\hline & & Informal trust \\
\hline & & Generalized trust \\
\hline & & Trustworthiness \\
\hline & & Sense of ecurity \\
\hline & \multirow{5}{*}{ Norms } & Acceptance of diversity and inclusiveness \\
\hline & & Sense of effectiveness and efficacy \\
\hline & & Value of life \\
\hline & & Social intervention \\
\hline & & Economic-social support \\
\hline & \multirow{3}{*}{ Networks } & Social participation \\
\hline & & Civic participation \\
\hline & & Social cohesion \\
\hline
\end{tabular}

In continue these concepts will be explained briefly:

- Trustworthiness: The amount of risk-taking and trustworthiness in terms of individual (the absence of theft and fraud) [12].

- Sense of security: The feeling of security, comfort and quietness at their homes or safety walking down streets day and night [13]. 
- Cooperation: This norm refers to inner sense of people for helping others and the society in which they live so it causes balance between individual and collective interests [14].

- Collaboration: To work with others to achieve a result or common goal [12].

- Acceptance of diversity and inclusiveness: Represent how much people accept and respect norms, life style and different beliefs of theirs [15].

- Sense of effectiveness and efficacy: understanding and imagination of people and communities to the ability of affectivity in activities and process of society [16].

- Value of life: The individual's sense of satisfaction about life and feeling valuable in the society also believing that the society respect them reciprocally [13].

- Social intervention: Active attendance as an intervener to resolve disputes and quarrels between acquaintances, neighbors, colleagues or citizens [15].

- Social support: Financial and emotional support of people to each other which is in the time of need or as a part of everyday life available [16].

- Social participation: The types of participation which brings satisfaction for the individuals, form relations and construct potential supportive networks [15].

- Civic participation: Activities related to political environment, government, club management and associations also NGOs which is usually in the form of formal membership and follows regulation and hierarchy [12].

- Social cohesion: The feeling of acceptance by others and sense of comfort in neighborhood, local community and membership or participation groups [12].

\section{THE EVALUATION OF SOCIAL CAPITAL LEVEL IN HISTORIC TISSUE OF KERMAN}

\subsection{Measurement Patterns}

According to the evaluation of social capital it is generally essential to note that the most completed definition of social capital is multi-dimension and considers various social levels and units. As a result, defining it needs to consider different dimensions. Moreover, any attempt to evaluate the properties of vague concepts such as: society, network and 
organization, is basically controversial. Despite all these disputes, there are patterns that are trying to use the method for presenting a quantitative analysis of social capital. Most of the patterns are influenced by the approaches of presenters and consider the social capital only in terms of social, cultural and political and some others proceeding based on economy. In general, the measurement patterns of social capital are separable into two main approaches [17].

\subsubsection{Measurement Pattern Based on the Properties of Social Groups}

This pattern which is related to Robert Putnam is formed from number of social groups (i) and also number of their members $(\mathrm{N})$ and so $\left(\sum \mathrm{Ni}=\mathrm{SC}\right)$. Based on this pattern, a society with more social groups and members has high social capital. Fukuyama adds group cohesion and relation with other groups to this pattern. So he believes that society with high membership numbers, trust to each other, being coherent and also in relation to outside can act effectively and create reciprocal cooperation with other societies (Fukuyama, 1999).Although evaluation with this pattern is almost easy but studies show that not so accurate and suitable approximation of social capital.

\subsubsection{Measurement Pattern Based on Survey}

In this pattern which is tried on the basis of survey, the required data about the trust between the members of a social system and their tendency to be in civic organizations or similar factors and element is measured. There are many examples and instances in this case as can be asserted that the major applied researches in social capital are done by questionnaire and interview with pre-selected samples or they conduct to analyze the previous statistics which are done through other surveys. A survey done by American Social Capital Association is a well-known sample about this [17].

\subsection{Applied Indicators in Evaluation of Social Capital}

In various studies, different indicators are used for the evaluation of social capital level. Table 2 presents the most important indicators applied for these studies. 
Table 2. The considered indicators for social capital in different contexts

\begin{tabular}{|c|c|c|}
\hline Row & Indicators & References \\
\hline 1 & Trust and reliability & $\begin{array}{l}\text { Bullen and Onyx (1998), Krishna and Shrader } \\
\text { (2000), Benchmark Survey(2000), Australian } \\
\text { Bureau of Statistics (2003),Grootaert and } \\
\text { others(2005) }\end{array}$ \\
\hline 2 & Social participation & $\begin{array}{l}\text { Bullen and Onyx(1998), BenchmarkSurvey } \\
\text { (2000),Australian Bureau of Statistics(2003) }\end{array}$ \\
\hline 3 & Civic collaboration & $\begin{array}{l}\text { Bullen and Onyx(1998), Rose (1998),Benchmark } \\
\text { Survey(2000), Australian Bureau of } \\
\text { Statistics(2003), Grootaert and others } \\
(2005)\end{array}$ \\
\hline 4 & Cooperation & $\begin{array}{l}\text { Krishna and Shrader(2000), Benchmark } \\
\text { Survey(2000), Australian Bureau of Statistics } \\
(2003)\end{array}$ \\
\hline 5 & Collaboration & $\begin{array}{l}\text { Krishna and Shrader(2000), Australian Bureau of } \\
\text { Statistics(2003), Grootaert and others(2005) }\end{array}$ \\
\hline 6 & $\begin{array}{l}\text { Acceptance of } \\
\text { diversity and } \\
\text { inclusiveness }\end{array}$ & $\begin{array}{l}\text { Benchmark Survey(2000), Australian Bureau of } \\
\text { Statistics (2003) }\end{array}$ \\
\hline 7 & Sense of security & $\begin{array}{l}\text { Bullen and Onyx (1998), Australian Bureau of } \\
\text { Statistics (2003) }\end{array}$ \\
\hline 8 & $\begin{array}{l}\text { Social } \\
\text { support(financial and } \\
\text { emotional) }\end{array}$ & $\begin{array}{l}\text { Benchmark Survey(2000), Australian Bureau of } \\
\text { Statistics (2003) }\end{array}$ \\
\hline 9 & Social cohesion & $\begin{array}{l}\text { Krishna and Shrader (2000), Grootaert and others } \\
(2005)\end{array}$ \\
\hline 10 & Truthfulness & spilberg, (2001), groter(2001) \\
\hline 11 & Value of life & $\begin{array}{l}\text { Bullen and Onyx (1998), Australian Bureau of } \\
\text { Statistics (2003) }\end{array}$ \\
\hline 12 & $\begin{array}{l}\text { Feel effectiveness and } \\
\text { efficiency }\end{array}$ & $\begin{array}{l}\text { Benchmark Survey (2000), Australian Bureau of } \\
\text { Statistics (2003) }\end{array}$ \\
\hline
\end{tabular}

In this article four indicators are selected. The indicators are: Trust, Social participation, Sense of security and Collaboration. In the following a brief explanation about the denotation of these four indicators is presented.

3.2.1. Trust: Trust of acquaintances (family, relatives, friends, colleagues and neighbors), trust of strangers, different organizations and government representatives (managers and members of parliament). 
3.2.2. Social Participation: Types of participations that bring satisfaction for both the individual and form the relationships and construct the network of potential support (such as meeting friends and relatives, attendance in the celebrations and funerals of neighborhoods, go to cinema, park, mountain and etc. altogether.

3.2.3. Collaboration: Cooperation in mass to achieve a common result or goal (such as neighbors working together to improve neighborhood, cooperation with local authorities and voluntary participation in community).

3.2.4. Sense of Security: Safety of households, comfort and quietness at their homes or safety walking down streets day and night [18].

\subsection{Data Collection and Analysis}

In in this study, at first a questionnaire has been designed and distributed among people then the data of four indicators of Trust, Social participation, Collaboration, Sense of security, analyzed and for each one a quantitative number achieved. Next, the four indicators were evaluated by using hierarchical analysis, then the quantitative indicator of social capital was obtained by using total number of evaluated indicators.

\subsubsection{Sampling Method}

The sampling method of this study is random. The sampling was done by using urban blocks of historic tissue. That is, the major blocks were selected and in each a few blocks as subgroup and in each sub-block 2 to 3 lanes and from every lane a number of registration plate selected. Then the inquisitor completes the questionnaire by referring the home.

\subsubsection{Questionnaire}

In the design of questionnaire, two choice questions (yes or no) were used. The indicators would be evaluated by different questions. The trust indicator includes questions about trust of friends, neighbors, police, state and local officials and etc. social participation about local community event and attendance at them, interaction with neighbors and etc. collaboration about the willingness of neighbors to work together for improving the neighborhood, the tendency to voluntary participation and etc. The sense of security includes the feeling of security, comfort and quietness at their homes or streets of this tissue. After the questionnaire design, the pre-test stage was done in the faculty of arts and architecture at university of Yazd, 
to evaluate ambiguous points and probable misinterpretations, so accordingly possible changes would be done. Sending and completing the questionnaire, the results were analyzed in percentage terms.

\subsubsection{Designing AHP Matrix for Evaluating to Each Indicator}

The Analytical Hierarchy Process (AHP), is a method of evaluating factors influencing a variable. In this method a matrix is considered and the factors which in relation to a specific topic may seem important, placed besides rows and columns. Then the experts will be asked to define the importance of row factors comparing with column factors. It's clear that by feeling the top half of matrix there is no need to fill down half, because the importance of these factors is on the contrary to the top factors (fig.2)

\begin{tabular}{ccccc}
\hline & Trust & Social participation & collaboration & Sense of security \\
\hline Trust & 1 & & & \\
\hline Social participation & & 1 & 1 & \\
\hline collaboration & & & 1 \\
\hline Sense of security & & & & 1 \\
\hline
\end{tabular}

Fig.2. AHP matrix sample submitted to experts

In this study for four selected indicators, a four in four matrix was designed to assess the relative importance of each one. This matrix was completed according to the professors and experts. In figure 3 the matrix shows the resulting comments of these people.

\begin{tabular}{ccccc}
\hline & Trust & Social participation & collaboration & Sense of security \\
\hline Trust & 1 & 3.5 & 4.5 & 5 \\
\hline Social participation & 0.31 & 1 & 2 & 3.5 \\
\hline collaboration & 0.21 & 0.46 & 1 & 1.5 \\
\hline Sense of security & 0.2 & 0.26 & 0.65 & 1 \\
\hline
\end{tabular}

Fig.3. Relative weight given by experts to indicators in compare with each other 
By using the above matrix and applying standard method, the value of each four indicators in social capital would be obtained. Table 3 shows the weight of each indicator in social capital.

Table 3. The weight of each indicator in social capital

\begin{tabular}{ccc}
\hline Row & Indicator & Weight \\
\hline 1 & Trust & 0.56 \\
\hline 2 & Social participation & 0.23 \\
\hline 3 & Collaboration & 0.12 \\
\hline 4 & Sense of security & 0.08 \\
\hline
\end{tabular}

\subsubsection{The Questionnaire Data}

Assessing and analyzing the questionnaires, the quantitative measure of trust, social participation, collaboration, and sense of security were achieved dividedly. In this way that positive responses point one and negatives, zero. Table 4 represents the quantitative rate of each of the four above indicators in percentage terms.

Table 4. The quantitative number of each indicator

\begin{tabular}{ccc}
\hline Row & Indicator & Quantitative rate(percentage) \\
\hline 1 & Trust & 20 \\
\hline 2 & Social participation & 21 \\
\hline 3 & Collaboration & 37 \\
\hline 4 & Sense of security & 18 \\
\hline
\end{tabular}

By using table of weights (table 3 ) and obtained number of table 4 , the final number of social capital will be achieved as follows:

$$
20 * 0.56+21 * 0.23+37 * 0.12+18 * 0.08=21.91
$$

\subsubsection{The Comparison of Social Capital Level in Historic Tissue of Kerman with the Social Capital Level in Province.}

Shabani and Soleimani in a research titled "The Evaluation of Social Capital Level in Provinces of Country" declared the rate of social capital indicator in country's provinces as 
follows (Table5):

Table 5. The rate of social capital indicator in Iran's provinces

\begin{tabular}{|c|c|c|c|c|c|}
\hline Row & Province & $\begin{array}{c}\text { Social } \\
\text { capital } \\
\text { (percentage) }\end{array}$ & Row & Province & $\begin{array}{c}\text { Social } \\
\text { capital } \\
\text { (percentage) }\end{array}$ \\
\hline 1 & East Azerbaijan & 59.51 & 16 & Fars & 57.30 \\
\hline 2 & West Azerbaijan & 57.20 & 17 & Qazvin & 65.17 \\
\hline 3 & Ardabil & 65.23 & 18 & Qom & 61.55 \\
\hline 4 & Esfahan & 60.91 & 19 & Kurdistan & 49.78 \\
\hline 5 & Elam & 49.81 & 20 & Kerman & 51.61 \\
\hline 6 & Blusher & 54.36 & 21 & Kermanshah & 49.16 \\
\hline 7 & Tehran & 53.27 & 22 & $\begin{array}{c}\text { Kohgiluyeh and } \\
\text { Boyer Ahmad }\end{array}$ & 56.14 \\
\hline 8 & $\begin{array}{c}\text { Chaharmahal and } \\
\text { Bakhtiari }\end{array}$ & 55.23 & 23 & Golestan & 60.39 \\
\hline 9 & South Khorasan & 59.95 & 24 & Gilan & 62.77 \\
\hline 10 & Razavi Khorasan & 56.29 & 25 & Lorestan & 61.28 \\
\hline 11 & North Khorasan & 53.00 & 26 & Mazandaran & 63.07 \\
\hline 12 & Khuzestan & 59.94 & 27 & Markazi & 56.37 \\
\hline 13 & Zanjan & 67.34 & 28 & Hormozgan & 52.57 \\
\hline 14 & Semnan & 69.06 & 29 & Hamadan & 61.75 \\
\hline 15 & $\begin{array}{l}\text { Sistan and } \\
\text { Baluchistan }\end{array}$ & 55.56 & 30 & Yazd & 67.59 \\
\hline
\end{tabular}

As it is represented in the above table, the level of social capital in Kerman province is 51.61 percent; meanwhile the level of social capital in historic tissue of Kerman is 21.91 percent, so it shows the low level of social capital in this tissue. 


\section{SUMMARY AND CONCLUTION}

As stated earlier, the social capital as one of the most important development factors is considered a key concept in new attitude to planning and urban management. In this attitude, observing the planning is from down to up and emphasizes the human resources, social capitals and collective participation of the inhabitants of a society. Having social capital causes people to use other capitals such as intellectual and financial capitals for progress of their life environment; in other words the effect of social capital level on the rate of inhabitant's participation in improvement plan of neighborhoods is proved and causes to increase the implementation of development plans related to this tissue. It also makes the progression of social position of the tissue in the society context. All the stated subjects demonstrate the necessity of attention to social capital level in a society as a key factor for achieving a comprehensive development.

Some promoting affairs on the subject of the growth of social capital in a habitation place are as follows:

- The improvement of economic condition and welfare with emphasis on disadvantaged and low-income groups to provide leisure time and spend it in social activities.

- Using special policies related to the creation of labor market, minimum wage requirements and laws relating to unfair deportation in order to remove economic barriers of developing community life.

- Emphasis on the need to comply urban reconstruction projects with participatory pattern and preserve social contexts to prevent destruction of neighborhood identities and cultural context of communities live in old tissues.

- Emphasis on the importance of urban open spaces in creating social intercourse between different groups, encourage neighborly relations, obligate urban projects and management institutions to provide space requirements for civic life settlement in cities.

- Emphasis on using the capacity of activities, clubs and athletic events to increase identity acceptance of community and social relations. 
- Struggle for development of tourism facilities with social goals and also increase and facilitation of relations between ethnic and cultural groups.

- Use the ceremonies, national and cultural celebrations to strengthen relations between people and social groups and also remove effective factors on social exclusion of people and groups in these events.

- Fortify social and religious norms encouraging interaction, cooperation and public benefit production such as collective worship, honesty, cordiality, good opinion, respect the rights of people and etc. through the effectiveness of associative actions based on these norms in society.

- Increase the commitment to law enforcement, justice establishment and non-discrimination in order to create confidence in social actor.

- Propagate and encourage social groups in performing the role at civil society through authorization and empowerment.

- Produce cultural projects to reinforce community life and encourage voluntary activities.

- Try to introduce identity factors in urban spaces for creating sense of belonging and stimulant to collaborative activities in citizens of different neighborhood and cities.

- Obligation to public report of survey results and citizens' judgments about institution and organization performance for creating trust of social participation effectiveness.

- Impose tax rebate for organization or rich people for social support activities.

- Develop the activities of associations, art and cultural centers as the most important means of promoting participatory skills.

- Meaningful empowerment of vulnerable groups of society like women, through relevant institution by enjoying improvement chances of collective activities.

- Investigate and identify skills and educational requirement of different social groups for collective activities, production of knowledge skill and skill growth packages by civil teaching institutions.

- Facilitation of formation processes, registration and licensing of social groups, reduction of bureaucracy and cumbersome administrative rules. 
- Provide security of collective activities and social group meetings.

- Support community activities in relation to equipment and development of funds and establishment of groups.

- Prevent discrimination in giving government supports as lead to improvement or depression of activities of special groups.

- Predict and prepare a social space for communication between citizens and create friendly relationships among people.

\section{ACKNOWLEDGEMENTS}

We are using this opportunity to express our gratitude to Mrs Roghayeh Eshaghi for providing language help and editing assistance. We are thankful for her aspiring guidance and friendly advices.

\section{REFERENCES}

[1] Zangene, Yaqub, Seyed Hossein Abedi, Toktam Roshandel, Reza Nabipur. The Impact of Place Belonging and Social Capital on Participatory Improvement of Old Neighborhood, Sample case: Sarde Sabzevar. Journal of Urban Planning and Researches P.,2014,19:111-128.

[2] Field, John. Social Capital.,2008.

[3] Pakseresht, Soleiman . Consideration and Strategies to Improve Social Capital, Journal of Culture Strategy .,2014.25: 71-104.

[4] Kalantar, Kianoosh and Kourosh Bararpur. New Patterns in Evaluation of the Stability of Development. Journal of Tadbir.,2006, no.18.p.2.

[5] Zahedi Mazandarani M. Development and Inequality. Tehran: Maziar Publication .,2003.

[6] Woolcock, Michael and Deepa Narayan. (2000). Social Capital : Implications for Development Theory, Research and Policy, The World Bank Research Observer,15(2): 225249.

[7] Portes, A. The Two Meanings of Social Capital. Sociological Forum.,2000, 15. (1). 1-12.

[8] Bourdieu P. The Form of Capital, in J. C Richardson (ed), Handbook of Theory and Research for the Sociology of Education, Greenwood Press,New York.,1986, pp 241-258. 
[9] Colman,J,S. Social Capital in the Creation of Human Capital, American Journal of Sociology., 1998, 94:95-120.

[10] Putnam, R. D. Bowling Alone: The Collapse and Revival of American Community, New York: Simon \& Schuster.,2000.

[11] Sharepur, Mahmoud. World Process in Assay of Social Capital. Journal of Management \& Development Process, The Erosion of Social Capital, Consequences, Tehran: Iran Sociology Institution.,2008, 69: 5-29.

[12] Grootaert, christiaan, DeepaNarayan,VeronicaNyhanJones and Michael woolcock.Measuring Social Capital an Integrated Questionnaire, world bank working. paper no.18, 2005.

[13] Bullen P and jenny onyx. Measuring Social Capital in Five Communities in NSW, neibourhood and community centers. Journal of Applied Behavior., 1998, vol.36, No. 1.

[14] Krishna, anirudh and Elizabeth shrader. Cross-Cultural Measure of Social capital :a tool and results from India and Panama, Washington DC: world bank social capital initiative.,2000. paper no.21.

[15] Esmaili Reza, Qasemi Vahid and Rabiee Karman. Leveling of Social Development Indicators in the Cities of Esfahan Province. Journal of Social Welfare .,2006,23: 225-248.

[16] Australian bureau of statistics. "Social Capital and Social Well Being", August 2003.

[17] Alavi, Seyed Babak. The Role of Social Capital in Development, Journal of Policy.,2001, no.116.12:34-40.

[18] Shabani, Ahmad and Mohammad Suleimani. Evaluation and Ranking of Social Capital Level in Country Provinces, Journal of Islamic Economic Studies., 2009, 2: 95-119.

\section{How to cite this article:}

Najmeh Eshaghi A, Hamid Mohammadi B. Evaluation of Social Capital in Historic Urban Tissue (Case Study: The historic tissue of Kerman city). J. Fundam. Appl. Sci., 2016, 8(3S), 769-785. 